\title{
Træk fra den administrative genforening
}

\author{
af Hans Schultz Hansen
}

En hovedhjørnesten i »de sønderjyske landsdeles« indlemmelse i Danmark var indførelsen af dansk administration. Arkivar Hans Schultz Hansen, Landsarkivet for Sønderjylland, giver her et rids over kontinuitet og brud på udvalgte områder af den statslige lokalforvaltning.

\section{Indledning}

"Ved de love, hvorved de sønderjydske landsdele inddrages under dansk lovgivning og forvaltning, er det tilstræbt, at landsdelen helt skal gå op i Kongeriget Danmark som en bestanddel af dette uden at bevare noget provinsielt særpræg«. Så knapt og præcist udtrykte udgiveren af Kongelig Dansk Hof- og Statskalender det officielle Danmarks holdning til Nordslesvigs administrative genforening med Danmark i 1920, da der i forbindelse med indlemmelsen blev udsendt et tillæg til Hof- og Statskalenderen. ${ }^{1}$

Ordene lød nærmest som en fjern genklang af Orla Lehmanns proklamation fra 1838: "Der gives i Danmark ingen provinser, der gives kun eet Danmark, beboet af danske! Danske af samme æt, med samme historie, et eneste udeleligt folk med fælles karakter og sæder, fælles sprog og litteratur, med fælles minder og forhåbninger ... «. ${ }^{2}$ I forholdet til Slesvig udtrykte dette dengang en målsætning, men i 1920, efter det tidligere hertugdømmes deling og det tysksindede Sydslesvigs forbliven ved Tyskland, kunne målet om Danmark som den nationale enhedsstat endelig realiseres. Tidens tolkning af den nationalhistoriske erfaring forbød Danmark at give Nordslesvig en særstilling, som kunne danne udgangspunkt for en senere løsrivelse, således som det var sket, da Slesvig i 1200-tallet var blevet et selvstændigt hertugdømme.

Idealet om fuldstændigt at slette Kongeågrænsen deltes af alle dem, der deltog $i$ arbejdet med at forberede den administrative indlemmelse af den genforenede del af Sønderjylland. Men også dette ideal stødte på vanskeligheder i virkelighedens komplicerede verden, og det blev nødvendigt at indgå kompromisser og acceptere kortere eller længere overgangsordninger, hvor elementer fra den preussiske administration blev videreført, og hvor Kongeåen stadig satte skel.

Central for hævdelsen af den nye danske suverænitet i den genvundne lands- 
del var den statslige lokaladministration. Dens opbygning skal i det følgende beskrives for udvalgte forvaltningsgrene med særlig hensyntagen til de tillempninger og overgangsordninger, som trods alt måtte foretages for at få skiftet fra tysk til dansk administration til at glide.

\section{De forberedende organer}

Centraladministrationens arbejde med at forberede landsdelens overgang til dansk styre lå dels i de enkelte fagministerier, dels i Det midlertidige Ministerium for sønderjydske Anliggender, som blev oprettet den 24. juni 1919 med de danske sønderjyders politiske leder, rigsdagsmand H.P. Hanssen, som minister og Martin Hammerich som kontorchef. Den 16.januar 1920 nedsatte ministeriet et udvalg til at gennemgå de sønderjyske lovforslag.

Da kong Christian X efter påvirkning fra tilhængerne af en grænse syd for Flensborg den 29. marts 1920 afskedigede den radikale regering C. Th. Zahle og dermed indledte den såkaldte »Påskekrise«, blev også H.P. Hanssen bragt til fald og hans ministerium opløst, idet ingen ny minister for de sønderjyske anliggender blev udpeget. Ministeriets arbejde blev fra den 12. april overtaget af Statsministeriet indtil opgaven ansås for fuldført i november 1920. Hovedparten af det lovforberedende arbejde var dog afsluttet før påskekrisen. ${ }^{3}$

Et andet center i forberedelsen af Genforeningen var "Rigsdagspartiernes sønderjyske Udvalg«, som var et mellemled mellem regeringen og partierne. Udvalget holdt sit første møde den 29.april 1919 og sit sidste den 24.juni 1920. De trykte stenografiske referater af udvalgets 45 møder fylder godt 1600 tætskrevne sider og er en vigtig kilde til de politiske synspunkter på overgangen. ${ }^{4}$

\section{Administrator for de sønderjyske landsdele}

Overgangen fra tysk til dansk styre skete ikke med ét hug, men strakte sig over et halvt år. Fra den 10. januar til den 15. juni 1920 blev 1. og 2. afstemningszone efter Versaillesfredens artikel 109 administreret af $»$ Den internationale Kommission « (C.I.S.). I henhold til samme artikel var Danmark imidlertid berettiget til efter nærmere aftale med kommissionen at besætte den første afstemningszone med dansk militær og civiladministration straks efter, at et dansk flertal ved afstemningen her var officielt bekendtgjort. ${ }^{5}$ Af forskellige årsager fandt denne besættelse dog først sted den 5. maj 1920, knap tre måneder efter, at afstemningen den 10. februar havde vist et dansk flertal i zonen på $75 \%$. 
Til at styre landsdelen fra denne dato udpegede den danske regering stiftamtmanden i Ringkøbing, Viggo Rothe Haarløv, der tillige var designeret stiftamtmand over Haderslev amt. Som dansk "Administrator for de sønderjydske Landsdele« fik han til opgave »under samvirken med den internationale kommission i Flensborg og efter nærmere anvisning af den danske regering at udfærdige de bestemmelser af almindelig karakter for vedkommende landsdele, som den danske besættelse og administration udkræver i tidsrummet, indtil suveræniteten endelig overføres til Danmark ... . $^{6}$

Det nødvendiggjorde talrige forhandlinger med tyske embedsmænd, især den tyske afviklingskommissær, og det betød, at Haarløv fortsatte som administrator også efter, at de allierede og associerede magter efter grænsens endelige fastsættelse overdrog suveræniteten over 1.zone til Danmark den 15.juni. Fra denne dato og indtil Danmark den 9. juli indlemmede »de sønderjyske landsdele« bekendtgjorde han de nye anordninger, bekendtgørelser, cirkulærer m.v. i det særlige forordningsblad "Sønderjydske Kundgørelser «. ${ }^{7}$ Efterhånden som forhandlingerne med tyskerne faldt på plads og de nye embedsmænd trådte i funktion, mistede hvervet dog sin betydning, og den 30 . november afskaffedes den midlertidige stilling. ${ }^{8}$

\section{Amter, amtmænd og amtsassessorer}

Det øverste lag i den danske statslige lokalforvaltning var amterne. I spidsen for amtsforvaltningen stod dengang som nu amtmanden eller stiftamtmanden, dersom hans amt omfattede en stiftsby. Amtmanden var dengang formand for amtsrådet, og det gav posten en større tyngde i den administrative struktur, end den har haft siden 1970, hvor den amtskommunale ledelse overgik til den folkevalgte amtsborgmester.

Ved Genforeningen var det derfor vigtigt, at amterne som »overøvrighed « straks fik den rigtige inddeling og afgrænsning og den bedste ledelse. Indenrigsminister Ove Rode ønskede at bevare alle fire tyske kredse (Haderslev, Aabenraa, Sønderborg og Tønder) som danske amter, selvom de sønderjyske amter derved ville blive mindre end de kongerigske. Det ekstra arbejde, som overgangen fra tysk til dansk styre ville medføre, retfærdiggjorde efter Rodes mening dette.

Endvidere foreslog indenrigsministeren, at hver af de sønderjyske amtmænd fik tilknyttet en såkaldt amtsassessor, der som amtmanden skulle være kongeligt udnævnt. Denne stilling var en nyopfindelse. Dels skulle amtsassessoren aflaste amtmanden, dels skulle amtmand og assessor supplere hinanden, således at en kongerigsk amtmand fik en sønderjysk assessor og vice versa. Der- 

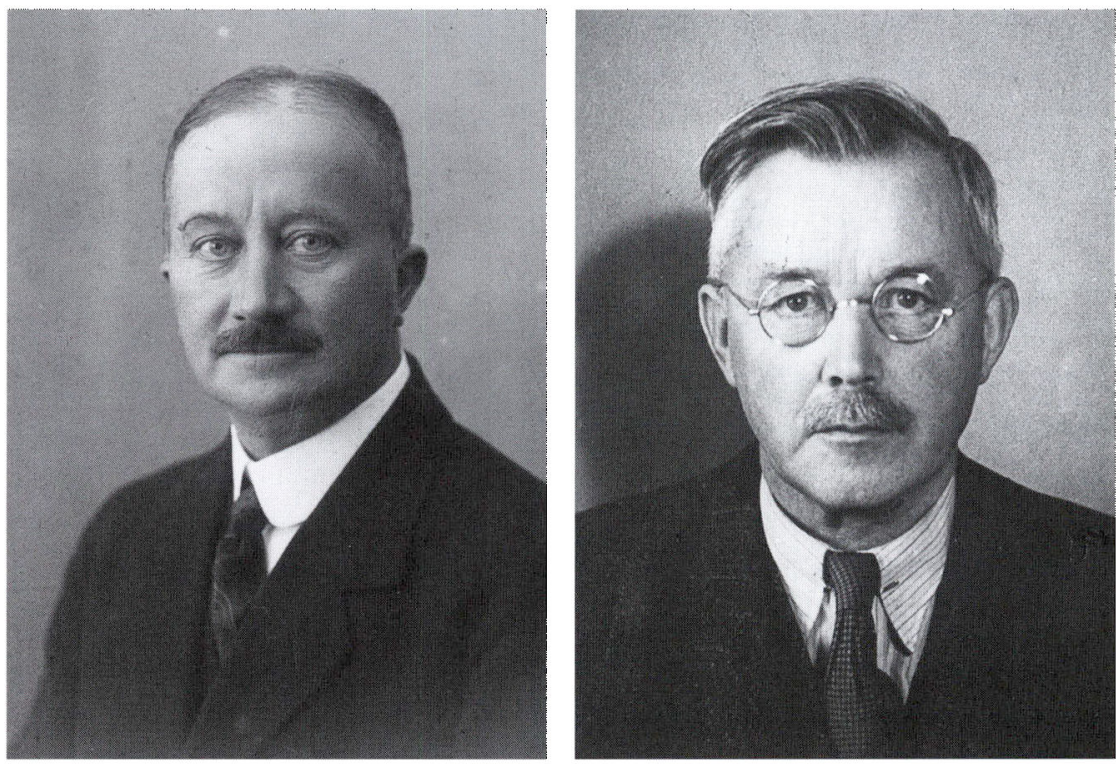

Den sonderjyske amtsadministration var 1920-27 et parlob mellem en sønderjysk fodt amtmand og en kongerigsk amtsassessor eller omvendt som i Haderslev, hvor Viggo Rothe Haarlov (1872-193I) var stiftamtmand og Jonathan Smith (1877-1968) amtsassessor. Haarlov (t.v.) sad i embedet til sin dod, mens Smith (t.h.) efter amtsassessorstillingens ophavelse $i 1927$ blev fungerende amtsforvalter $i$ Sonderborg. Han drev omfattende personalhistoriske studier over slesvigske embedsmand. Foto $i$ Institut for sonderjysk Lokalhistorie.

ved sikredes, at den øverste amtsledelse fik kendskab til såvel dansk som tysk administration og forhold $\mathrm{i}$ det hele taget.

Endelig kom assessorerne ind $\mathrm{i}$ billedet $\mathrm{i}$ en tredje sammenhæng. Det var Rodes tanke at opḥæve juristmonopolet fra 1821 på amtmandsstillingerne, som betød, at en amtmand skulle have juridisk embedseksamen med 1. karakter. Denne ophævelse var nødvendig, hvis der skulle udpeges sønderjysk fødte amtmænd, men Rode ønskede også generelt at lade f.eks. statsvidenskabelige kandidater få adgang til amtmandsposterne. ${ }^{9}$ Ved de amter, hvor en ikke-jurist blev udpeget, skulle amtsassessoren så repræsentere den juridiske ekspertise. Det generelle brud på juristmonopolet kom Rode nu ikke igennem med, men en undtagelse for de sønderjyske landsdele blev dog tilladt. ${ }^{10}$

Det særlige underudvalg for indførelse af dansk kommunal administration med venstremanden Klaus Berntsen som formand ønskede en nærmere argumentation for de fire amtmænd. Og den havde Ove Rode parat. Overgangen fra tysk til dansk lovgivning ville generelt give amtmændene et stort arbejde. Amtmændene ville især få en stor arbejdsbyrde som vejledere for de kommen- 
de kommunalpolitikere, der var helt ukendte med den danske kommunaladministration. Der skulle ske en stor udbygning på det amtskommunale område, særlig inden for sygehusvæsnet, hvor sønderjyderne var bagefter danske forhold. Desuden ville de sønderjyske amtmænd få overdraget administrationen af de tidligere preussiske kredsbaner og kredssparekasser, som begge var ukendte institutioner i kongeriget. Der var også en del arbejde som følge af overgangen fra krig til fred, som af gode grunde var langt større end i det øvrige land. Rode anførte også »nationale grunde« og de eksisterende amters "historiske berettigelse« samt befolkningens ønsker til støtte for sit forslag om de fire amter. ${ }^{11}$

Rodes argumenter overbeviste underudvalgets flertal, men ved diskussionen i det store udvalg mente socialdemokraten K. K. Steincke stadig, at fire amtmænd var i overkanten. Han ville forbeholde sig retten til »om 10 år at kunne sige, at der dog var én, der straks kunne se, at der var for mange amtmænd«. Venstremanden J.C.Christensen spurgte, om man ikke kunne lade én amtmand bestyre to amter. Hertil svarede H.P. Hanssen benægtende, men afviste ikke, at det kunne ske, når amtsbanerne var privatiserede eller blevet statslige, og når sammenlægningen af de mange små kommuner til sognekommuner var fuldbyrdet. Steincke og J.C. Christensen bøjede sig dog begge for underudvalgets flertal, som det store udvalg fulgte. ${ }^{12}$

Amternes grænser blev fastlagt efter nogen diskussion. At der måtte ske ændringer i forhold til de preussiske kredsgrænser, var så godt som givet på forhånd. Dels var fra Flensborg landkreds Bov sogn (med undtagelse af Kobbermølle og Nyhus kommuner), Hønsnap kommune i Holbøl sogn og Frøslev kommune i Hanved sogn indlemmet i første afstemningszone og dermed sikret for Danmark. Dels var den næsten rent tysksindede sydlige del af Tønder kreds omvendt holdt udenfor 1.zone. Fra Indenrigsministeriet foreslog man, at Bov, Hønsnap og Frøslev blev lagt til det nye Aabenraa amt, og at Hviding herred skulle overføres fra Haderslev kreds til det nye Tønder amt. Sønderborg kreds skulle med uændrede grænser videreføres som dansk amt (se kort).

Amterne fulgte den gamle Kongeågrænse. Det glædede beboerne i de tidligere slesvigske »otte sogne« syd for Kolding, som i 1864 var kommet til Danmark, da de hverken ville høre under Haderslev amt eller retskreds. ${ }^{13}$ Derimod var beboerne i det nordvestlige hjørne ikke umiddelbart tilfredse med afgrænsningen. Mens man i Skærbæk gerne ville til Tønder amt, foretrak beboerne i den nordlige del af Hviding herred med sognene Spandet, Roager, Hviding, Rejsby og Brøns at komme til Ribe amt. Det samme gjorde sognene Hygum og Fole i den del af Haderslev kreds, der skulle forblive ved Haderslev amt. Selv om disse ønsker fint var i tråd med den overordnede målsætning om 


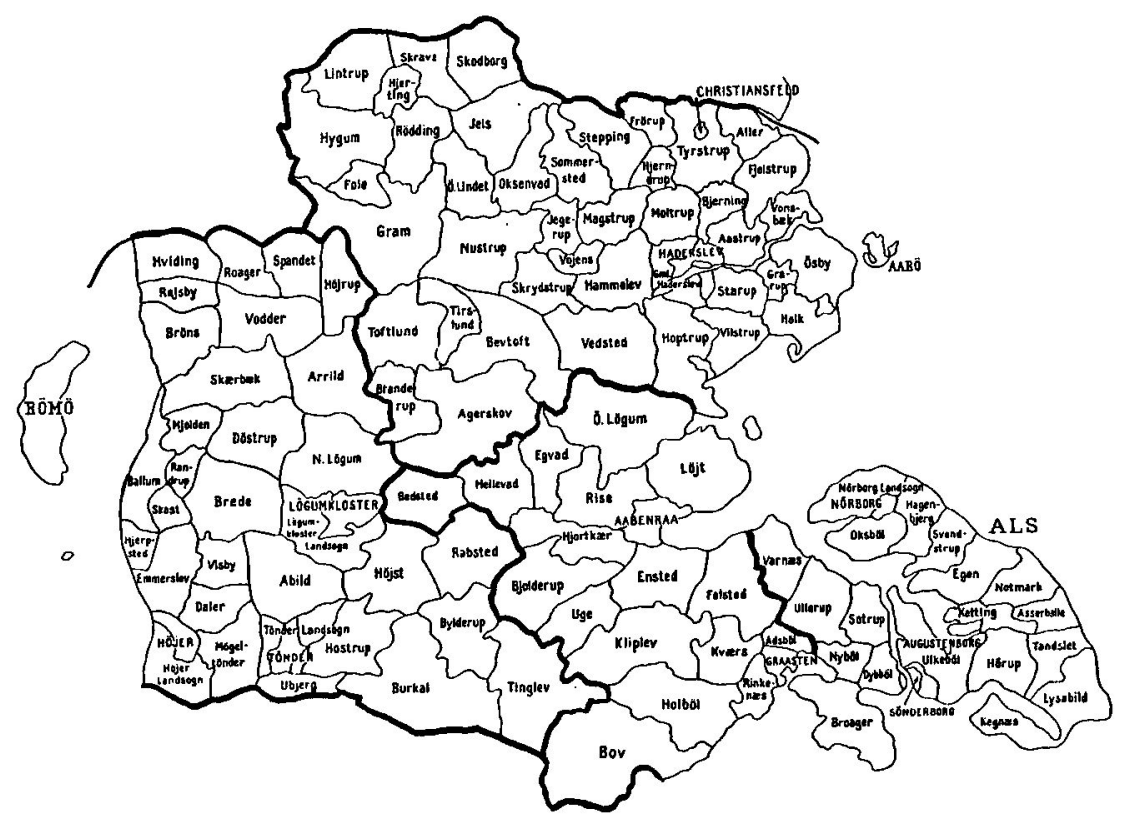

De sonderjyske amters granser fra 1920 til sammenlagningen af Aabenrau og Sonderborg amter $i 1932$. Onsker fra sognene Spandet, Roager, Hviding, Rejsby. Brons, Hygum og Fole om at komme til Ribe amt kunne ikke imodekommes.

at udslette Kongeågrænsen, blev de afvist af indenrigsminister Ove Rode. Dels ville det gøre det hele endnu mere kompliceret, hvis der til et rent dansk amt som Ribe blev lagt områder med overgangsproblemer. Og dels var der tungtvejende nationalpolitiske hensyn. Hviding herred var en udpræget dansk egn, som ville sende dansksindede repræsentanter til det kommende Tønder amtsråd, hvor der ville blive behov for dem til at begrænse den tyske indflydelse fra de mere tyskprægede områder sydpå. Det gjaldt specielt, hvis der ved afstemningen skulle komme sogne fra 2. zone med til Danmark. Endelig passede Hviding herred med diger, marskområder og kødkvægsproducerende landbrug bedre til Tønder end Haderslev amt.

H. P. Hanssen var enig med Rode, men påpegede dog, at beboerne i Hviding herred samt Hygum og Fole sogne i retslig henseende eventuelt kunne lægges til Ribes retskreds, for det havde ingen national betydning (se herom nedenfor). ${ }^{14}$

De fire nye amter blev etableret med loven om indførelse af dansk kommunal administration i de sønderjyske landsdele af 28 . juni $1920 .{ }^{15}$ Sammenlignet med de tidligere preussiske kredse fik de følgende størrelse: ${ }^{16}$ 


\begin{tabular}{lccccc}
\hline & \multicolumn{2}{c}{ De preussiske kredse: } & & \multicolumn{2}{c}{ De danske amter: } \\
\cline { 2 - 3 } \cline { 5 - 6 } Kreds/amt & Areal 1910 & Indbg. 1910 & & Areal 1920 & Indbg. 1921 \\
\hline Haderslev & 167.919 ha & 63.780 & & 135.242 ha & 56.255 \\
Aabenraa & 68.524 ha & 32.311 & & 79.153 ha & 35.073 \\
Sønderborg & 44.231 ha & 40.012 & & 44.231 ha & $36.675^{*}$ \\
Tønder & 181.970 ha & 59.360 & & 129.137 ha & 35.625 \\
\hline Ialt & 462.644 ha & 195.463 & & 387.763 ha & 163.628 \\
\hline
\end{tabular}

*Befolkningstilbagegangen på knap 4.000 skyldtes nedlæggelsen af marinestationen.

Aabenraa og Sønderborg amter var $\mathrm{i}$ henseende til såvel areal som befolkning meget små, og ved lov af 21.12.1931 blev de med virkning fra 1.4.1932 slået sammen til Aabenraa-Sønderborg amt, men opretholdtes dog som to selvstændige amtsrådskredse. ${ }^{17}$ Den derved lagte struktur for de sønderjyske amter videreførtes frem til sammenlægningen til Sønderjyllands amt i 1970.

Ordningen med amtsassessorerne bortfaldt ifølge anordning af 17.2.1927 fra 1. juni samme år. ${ }^{18}$

Til stiftamtmand over Haderslev stift og amtmand for Haderslev amt udnævntes administrator Viggo Haarløv, der fik Haderslevtandlægen Jonathan Smith som amtsassessor. ${ }^{19}$ Smith havde før 1920 været juridisk konsulent for Vælgerforeningen for Nordslesvig, udgivet flere tyske love med kommentarer samt ført en længere sag med. myndighederne om gymnastikundervisningen. Tillige havde Smith været medlem af Haderslev kredsdag og byråd. Han besad således et alsidigt kendskab til tysk lovgivning og til Haderslev amt.

I Aabenraa amt udnævntes Kresten Refslund Thomsen til amtmand. Han var født i Nordslesvig, men var cand.polit. fra Københavns Universitet og brød således juristernes amtmandsmonopol. Tillige havde han en kort tid studeret forvaltningsret $\mathrm{i}$ Berlin. Refslund Thomsen havde arbejdet $\mathrm{i}$ den danske bevægelses tjeneste som redaktør på »Hejmdal« og som arbejdersekretær for Vælgerforeningen. I afstemningstiden havde han fungeret som landråd under Den internationale Kommission. Som H. P. Hanssens svigersøn havde han nær berøring med landsdelens politiske udvikling. Som amtsassessor fik Refslund Thomsen den nordfra kommende Emil Johannes Carl Bang.

Sønderborg amt fik derimod en kongerigsk amtmand, Christian L. Lundbye, der kom fra en kontorchefstilling i Justitsministeriet. Han kendte til de sønderjyske forhold fra sin tid som Danmarks repræsentant ved Den internationale Kommission. Som amtsassessor fik han Andreas V. Karberg, der var født i Sønderborg og juridisk uddannet fra universiteterne i München, Berlin, Kiel og Jena. Før 1920 var han fuldmægtig i Sønderborg Bank. Også han havde været kredsdags- og byrådsmedlem og landråd under Den internationa- 
le Kommission. Fra 1920 til han i 1926 selv blev amtmand i Ringkøbing amt var Karberg medlem af Landstinget for Venstre.

I Tønder amt blev lensgreve Otto Didrik Schack, Schackenborg, udnævnt til amtmand. Han havde ingen akademisk uddannelse, men havde gennem mange år været kredsdagsmand og medlem af kredsudvalget og provinslanddagen. 1919-21 var Schack formand for Vælgerforeningen og fungerede i afstemningstiden som landråd under Den internationale Kommission. ${ }^{20}$ Hans amtsassessor blev Peter Chr.Stemann, der kom fra en stilling som fuldmægtig i Indenrigsministeriet.

Schack og Stemann tiltrådte den 6. maj, fortæller Stemann i sine erindringer, hvor han også beretter om de særlige vanskeligheder i Tønder, som fulgte af kredsens deling i en dansk og en tysk del. Det personale, som skulle overflyttes til det nye landrådskontor for den nye Sydtønder kreds i Nibøl, forsvandt således pludseligt uden at afslutte de verserende sager. Det voldte også vanskeligheder at dele landrådsarkivet. Der kom ingen anvisninger fra arkivvæsnet, og Stemann måtte selv foretage udleveringen. Da der endelig kom besøg fra arkivvæsnet, viste det sig, at udleveringen havde været for gavmild. ${ }^{21}$ I den daglige administration betød tabet af Sydtøndersagerne dog ikke noget særligt for Stemanns virke: "For mit eget vedkommende må jeg tilstå, at jeg faktisk aldrig åbnede en af de talrige aktsamlinger, som vi havde fra den tyske tid. Jeg var klar over, at man så ville være håbløst fortabt. Tiden tillod det ikke. Men når man anvendte sin menneskelige og juridiske retfærdighedssans som rettesnor, måtte det kunne gøres på den måde. Det var jo ikke meningen at gribe voldsomt ind; det hele skulle glide. Og det gjorde det «. ${ }^{22}$

I forhold til den tyske landrådsadministration var det ikke mindst personudskiftningerne, som havde betydning sammen med det nye retsgrundlag. Med hensyn til forretningsområderne adskilte den danske amtsadministration sig derimod ikke afgørende fra landrådsembedet. Hele det kommunale område var således fælles. Både landråden og amtmanden havde tilsynet med kommunerne, og hvor landråden var formand for kredsdag og kredsudvalg, stod amtmanden i spidsen for amtsrådet. Andre fælles sagsområder var kongehuset, rigsdagsvalg, statsborgerforhold, medicinalvæsen, veterinærvæsen, brandvæsen, forsikringsog forsørgelsesvæsen, næringssager, landboforhold, legater og stiftelser.

Tre vigtige forskelle var der dog. Modsat landråden varetog amtmanden en række familieretslige sager vedr. alimentation, skilsmisse og ægteskab samt børn og umyndige, som i den tyske tid havde ligget ved amtsretterne. Amtmanden stod derimod ikke for udskrivningsvæsnet (se nedenfor). I den danske amtsadministration var de såkaldte "underøvrighedsforretninger«, d.v.s. ordens- og kriminalpoliti, sikkerhedspoliti og erhvervspoliti, tillige siden 1919 overladt til politimestrene. 


\section{Politi og domstole}

I den preussiske statsforvaltning var politifunktionerne i købstæderne delt mellem landråden og det kommunale politi, på landet mellem landråden og amtsforstanderne. Sidstnævnte var typisk hjemmetyske gårdejere, der med hjælp af en gendarm udøvede politimyndigheden for 1-2-3 kirkesogne. Som lægmandspoliti mindede amtsforstanderne i princippet om de danske sognefogder, men deres sagsområde og kompetance var betydeligt større. ${ }^{23}$ Gendarmerne var organiserede som et militært korps med egne officerer. ${ }^{24}$

Ved overgangen til dansk styre faldt amtsforstanderinstitutionen og gendarmeriet bort til fordel for dansk politi. I kongeriget havde politivæsnet netop i 1919 gennemgået en reform, der adskilte den udøvende magt fra den dømmende. Det gamle herredsfogedembede blev delt mellem de nyoprettede stillinger som underretsdommer og politimester. Politimesteren var statstjenestemand og ligeså hans stedfortræder, politifuldmægtigen, men ellers var det lokale politipersonale kommunalt ansat og lønnet. Ved siden af dette lokale politi, som varetog ordenspolitiopgaverne, fandtes siden 1911 statspolitiet, der kunne operere over hele landet som kriminalpoliti til opklaring af vanskeligere sager og derudover kunne sættes ind ved større uroligheder. ${ }^{25}$

Justitsminister (og statsminister) C. Th.Zahle foreslog imidlertid, at også ordenspolitiet i den genforenede landsdel skulle være statsligt, da det kommunale politi i Sønderjylland var for spinkelt. Ordenspolitikorpset skulle bestå af op til 250 betjente og være en særlig afdeling under chefen for statspolitiet. Styrken skulle i det daglige ledes af en »politiadjudant«. Kommunernes eneste rolle blev at bidrage til finansieringen af de løbende udgifter. Loven skulle revideres i $1921 .{ }^{26}$ Kriminalpolitiet skulle som nord for Kongeåen varetages af statspolitiet.

I det sønderjyske udvalg var Klaus Berntsen (V) betænkelig ved at indføre en anden ordning end i det øvrige land, også selv om det kun blev en overgang, og han mente, at 250 var alt for mange. J.Andersen (R) kunne godt acceptere statspolitiet $\mathrm{i}$ en overgangsperiode, men kun indtil det sønderjyske kommunestyre var etableret og i stand til at løfte politiopgaven. I længden ville et statspoliti være for stort og tungt et apparat. Statsministeren søgte at berolige Berntsen og Andersen med, at loven skulle revideres i 1921. Bag i hvert fald Klaus Berntsens opposition lå formentlig en principiel uvilje mod at indføre et statsligt enhedspoliti, som ville svække det lokale selvstyre.

Klaus Berntsen understregede endvidere, at det var vigtigt, at så mange af de nye betjente som muligt var sønderjyder, så det kunne undgås at indsætte en større styrke, som var ukendt med de lokale forhold. Heri var justitsministeren helt enig. H.P.Hanssen forestillede sig ansættelse af en stor del af 


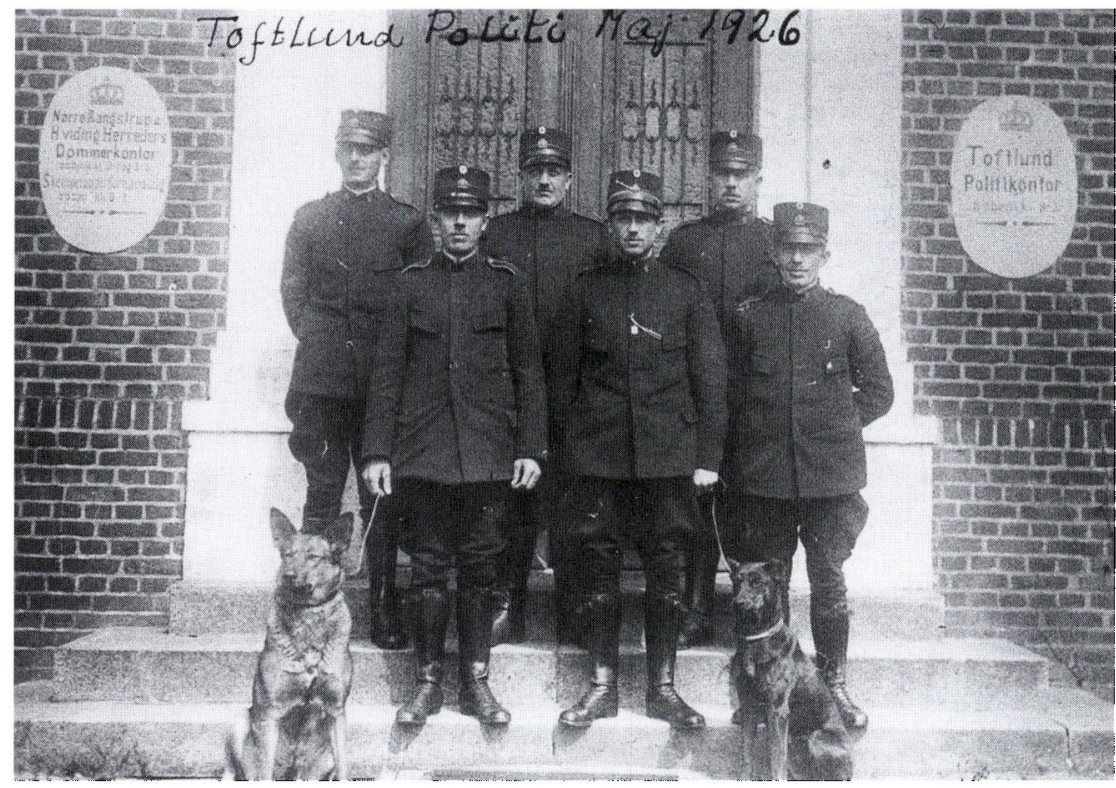

Det sonderjyske ordenspoliti var i modsatning til det kommunale ordenspoliti nord for Kongeåen statsligt. Her ses betjentene fra Toftlund politikreds i maj 1926: Nissen fra Rødding, Munck fra Jels, Christensen fra Gram, samt Skott, A. N. Jensen og Iversen fra Toftlund. Foto i Institut for sonderjysk Lokalhistorie.

de sønderjyske betjente, som skulle fungere som CIS-gendarmer $i$ afstemningstiden.

Trods betænkelighederne ved et statsligt ordenspoliti godkendte underudvalget vedr. indførelse af dansk kommunal administration i Sønderjylland ministerens udkast uden ændringer, og det samme gjorde hovedudvalget. ${ }^{27}$ Det udsendtes efter Danmarks overtagelse af suveræniteten som $»$ Lov af 28.juni 1920 om oprettelse af et under chefen for statspolitiet sorterende ordenspoliti i de sønderjydske landsdele «. ${ }^{28}$ Som »politiadjudant « (man søgte forgæves efter en bedre betegnelse) udpegedes cand.jur. Fritz Emil Jacobsen, der fungerede som sådan frem til udgangen af $1922 .{ }^{29}$ Rammen på 250 betjente blev det ikke nødvendigt at udnytte, og man kunne nøjes med at ansætte $150 .^{30}$

Blandt de 150 var A.N. Jensen fra Skærbæk, der som de fleste andre havde deltaget i den første verdenskrig. I oktober 1919 meldte han sig til et sikkerhedsværn på 30 mand, som det nu danskdominerede byråd i Haderslev oprettede. Her blev han værnets næstkommanderende. I januar blev han politiassistent for den internationale kommission for Haderslev vesteramt og ledede som sådan CIS-gendarmernes indsats dér. Som tidligere politiassistent under 
C.I.S. blev A. N. Jensen ansat i det danske statspoliti som overbetjent. Det gav nye uniformer og dermed en ny identitet: $» E t$ par dage efter 1.juli 1920 fik jeg besked om at give møde i Aabenraa, hvor mange af kollegerne fra hele Sønderjylland havde givet møde, og hvor vi nu fik udleveret den nye danske politiuniform. Den bestod af en høj kasket med guldtresser og kokarde, blå jakke med høj grøn krave og grønne skulderstropper. Der var ingen blanke knapper foran på jakken, endvidere ridebenklæder og lædergamacher. Uniformen var pæn og enkel«.

De nye danske betjentes første opgave blev ordensopgaverne i forbindelse med kong Christians indtog og Dybbølfesten. Derefter meldte hverdagens krav sig: »For os sønderjyske politimænd, der lige fra det civile liv var sprunget ind og udøvet en gerning som politimand, hvortil vi forinden ikke havde nogen kendskab, gjaldt det nu om at sætte sig ind i dansk lov og ret og lære de danske lovbestemmelser, som vi nu skulle administrere. Der skulle skrives rapporter, og det kneb for mange. Der var adskillige af de sønderjyske betjente, som ikke kunne og aldrig havde lært at skrive dansk. Men i årene efter genforeningen kom alle på flere kurser på politiskolen, hvor vi blev sat ind i dansk polititjeneste og lærte at skrive dansk. Enkelte af de antagne politimænd kunne ikke klare den efter hvert kursus afholdte eksamen på politiskolen og gled tilbage til civillivet .... ${ }^{31}$

Justitsministerens forsikringer om, at statspolitiet i Sønderjylland skulle være midlertidigt, kom imidlertid ikke til at holde stik. Loven blev forlænget flere gange, blandt andet fordi de sønderjyske købstæder ønskede det statslige ordenspoliti opretholdt. Byerne foretrak at betale staten for at varetage denne opgave frem for selv at organisere et kommunalt politi. Den sønderjyske særordning bortfaldt først i 1938, og da ikke fordi det sønderjyske ordenspoliti endelig blev kommunalt, men fordi også det øvrige ordenspoliti i Danmark blev statsligt med oprettelsen af et "enhedspoliti« under en rigspolitichef. ${ }^{32}$ Det statslige sønderjyske ordenspoliti blev således mere en spydspids- end en overgangsordning.

Det sønderjyske ordenspoliti stod i det daglige arbejde under de nye sønderjyske politimestres ledelse. Ved fastlæggelsen af politikredsene blev retskredsinddelingen lagt til grund, og her blev igen den gamle herredsinddeling og den preussiske inddeling i amtsretskredse brugt som udgangspunkt. I Justitsministeriets udkast til "Lov om domstolenes og politimyndighedernes ordning m. m. i de tidligere slesvigske landområder« var der regnet med otte underretskredse: ${ }^{33}$

1. Haderslev købstad, Haderslev og Gram herreder, en del af Tyrstrup herred.

2. Aabenraa købstad, Rise og Sdr. Rangstrup herreder, en del af Lundtoft herred og Varnæs birk. 
3. Sønderborg købstad, Nybøl herred, en del af Lundtoft og Vis herreder.

4. Als med undtagelse af Sønderborg.

5. Frøs herred og en del af Kalvslund herred.

6. Nr. Rangstrup og Hvidding herreder.

7. Lø herred og Løgumkloster birk.

8. Tønder købstad, Tønder, Højer og Slogs herreder.

Inddelingen i politikredse var i forslaget den samme, dog blev Haderslev vesteramt (nr. 5 og 6) lagt sammen til én kreds. Med H. P. Hanssens ord var det wtyndt befolkede egne med en solid befolkning, hvor der ikke er så store opgaver for politiet «. ${ }^{34}$

Befolkningen i syv sogne øst og syd for Ribe ønskede imidlertid ikke alene som ovenfor nævnt at komme under Ribe amt, men - overraskende nok! også under den Riber ret og dermed under denne bys politimester. Mens ønsket om at komme til Ribe amt som næunt blev afvist, var der lydhørhed i rigsdagspartiernes sønderjyske udvalg for at lade sognene udgøre en selvstændig retskreds med tingsted i Ribe eller at lægge sognene under Ribe rets- og politikreds. Dette tiltalte dog ikke justitsministeren, der afviste at involvere en kongerigsk rets- eller politikreds i de slesvigske overgangsordninger. Resultatet blev et kompromis. De syv sogne forblev under de retskredse, de i forslaget var henlagt til (nr. 5 og 6), men de fik et bitingsted med en kontorafdeling i Ribe. I politimæssig henseende blev sognenes ønske derimod fulgt, og de blev lagt ind under Ribes politimester. ${ }^{35}$ Et udvalgsmedlem ytrede betænkelighed ved, at det ville betyde en stor belastning for politimesteren i Ribe, men justitsministeren, der stadig ikke var overbevist om ordningens fortræffelighed, kunne meddele, at $w i$ hvert fald foreligger der en erklæring fra politimesteren $\mathrm{i}$ Ribe om, at han med stor elegance kan klare det hele $\ll{ }^{36}$ Mens de praktiske problemer ved overgangen til dansk styre var for store til, at Kongeågrænsen trods politikernes intentioner og lokalbefolkningens ønsker herom kunne slettes ved amtsinddelingen, lod et kompromis mellem de praktiske og ideelle hensyn sig finde ved retskredsinddelingen, og ved politikredsinddelingen opfyldtes de lokale ønsker, og Kongeågrænsen blev tilsidesat.

Udvalget foretog endnu en forandring i jurisdiktionsinddelingen. Sønderborg købstad m.v., rets- og politikreds (nr. 3), blev delt i to, således at de resterende dele af Lundtoft og Vis herreder kom til at danne egen rets-, men ikke politikreds. Denne nye afgrænsning blev fastlagt ved den endelige lov af 28. juni 1920 (se kort). ${ }^{37}$ Imidlertid blev kredsene allerede omlagt pr. 1.januar 1923. Fra Aabenraa købstad m.v. flyttedes Kliplev og Kværs sogne samt en del af Felsted sogn til Lundtoft og Nybøl herreder, der også modtog Ullerup og Nybøl sogne samt Egernsund fra Sønderborg købstad m.v. Mens Lundtoft 


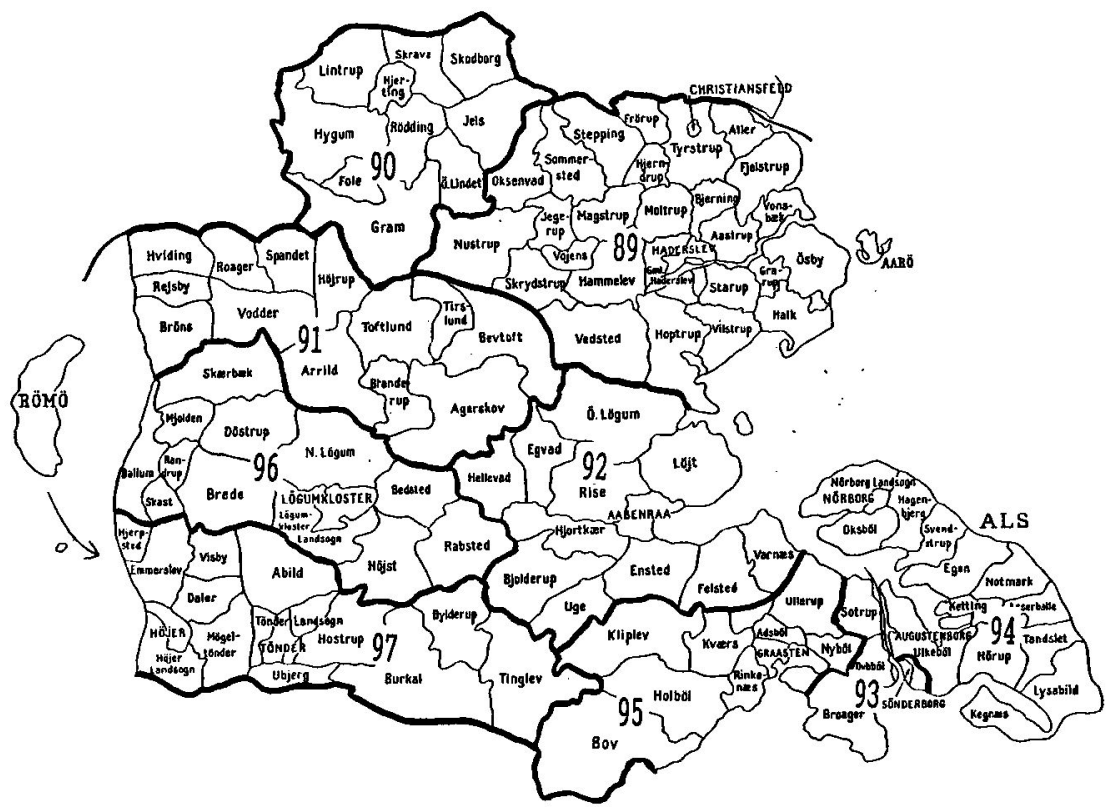

Den sonderjyske retskredsinddeling fra 1923 gjaldt frem til midten af 1950 'erne. Den 1.juli 1954 blev retskreds $n r .91$, Nr. Rangstrup og Hviding herreder, lagt ind under $n r .90$, Fros herred, idet retten $i$ Toftlund dog fortsatte som bitingsted. Samtidig blev sognene Spandet, Roager, Hviding, Rejsby og Brøns lagt til Ribe retskreds, således som det allerede havde varet drøftet i 1920. Den 1. marts 1957 blev retskredsene 93 og 94, Sonderborg kobstad m.v. og Als, lagt sammen. Derefter skete der ingen andringer for den generelle omlagning $i 1973$.

og Nybøl herreder hidtil havde haft politimester fælles med Sønderborg købstad m.v., fik de nu deres egen i Gråsten, og Sønderborg købstad m.v. fik i stedet politimester fælles med resten af Als. Vestpå blev Løgumkloster politikreds lagt ind under Tønder købstad m.v., mens retskredsen bestod. Skærbæk sogn flyttedes fra Nr. Rangstrup og Hviding herreder til Lø herreds retskreds og Tønder købstad m.v. politikreds (se kort). ${ }^{38}$

Med Genforeningen blev bestillingen som sognefoged påny indført i Nordslesvig. ${ }^{39}$

Mens de organisatoriske ændringer var gennemgribende for politiet, betød overgangen fra tysk til dansk styre ikke de voldsomme forandringer i underretternes opbygning. Der blev oprettet ni underretter: i Haderslev med 3 dommere, Aabenraa og Tønder med hver to dommere og én dommer i Rødding, Toftlund, Gråsten og Løgumkloster. I Sønderborg havde de to underretter for h.h.v. Sønderborg-Sundeved og Als hver én dommer. ${ }^{40}$ For at sikre retterne med de nordfra kommende dommere juridisk kompetance i spørgsmål, hvor 
tysk ret skulle indgå $i$ afgørelserne, blev der givet mulighed for at ansætte fem ekstra dommere, der var kvalificerede til at være dommere i Tyskland samt indtil udgangen af 1921 at ansatte særlige retsfuldmægtige med tysk referendareksamen, altså en parallel til amtsassessorerne. ${ }^{41}$

Endvidere blev der for de fire sønderjyske amter oprettet en ny appelinstans, Søndre Landsret, til erstatning for landretten i Flensborg. Dermed fik Danmark sin tredje landsret ved siden af Østre Landsret i København og Vestre Landsret i Viborg. Søndre Landsret blev ledet af en præsident og fik fire landsretsdommere. Også her kunne der ansættes retsfuldmægtige med kendskab til tysk ret. Endvidere blev der beskikket en statsadvokat for Søndre Landsret. Etableringen af Søndre Landsret skete uden politiske modsætninger. Landsretten fik sæde i Sønderborg. ${ }^{42}$ Imidlertid nedlagdes Søndre Landsret allerede pr. 1.januar 1928 for at komme under Vestre Landsret, mens statsadvokaturen fortsat består som 3. statsadvokatur i Vestre Landsretskreds. ${ }^{43}$

Mere gennemgribende end de organisatoriske ændringer var forandringen i selve det retsgrundlag, domstolene og administrationen skulle træffe deres afgørelser på. Overgangen fra tysk til dansk ret kunne imidlertid ikke klares i ét hug, og der måtte mange midlertidige bestemmelser til, der opretholdt det

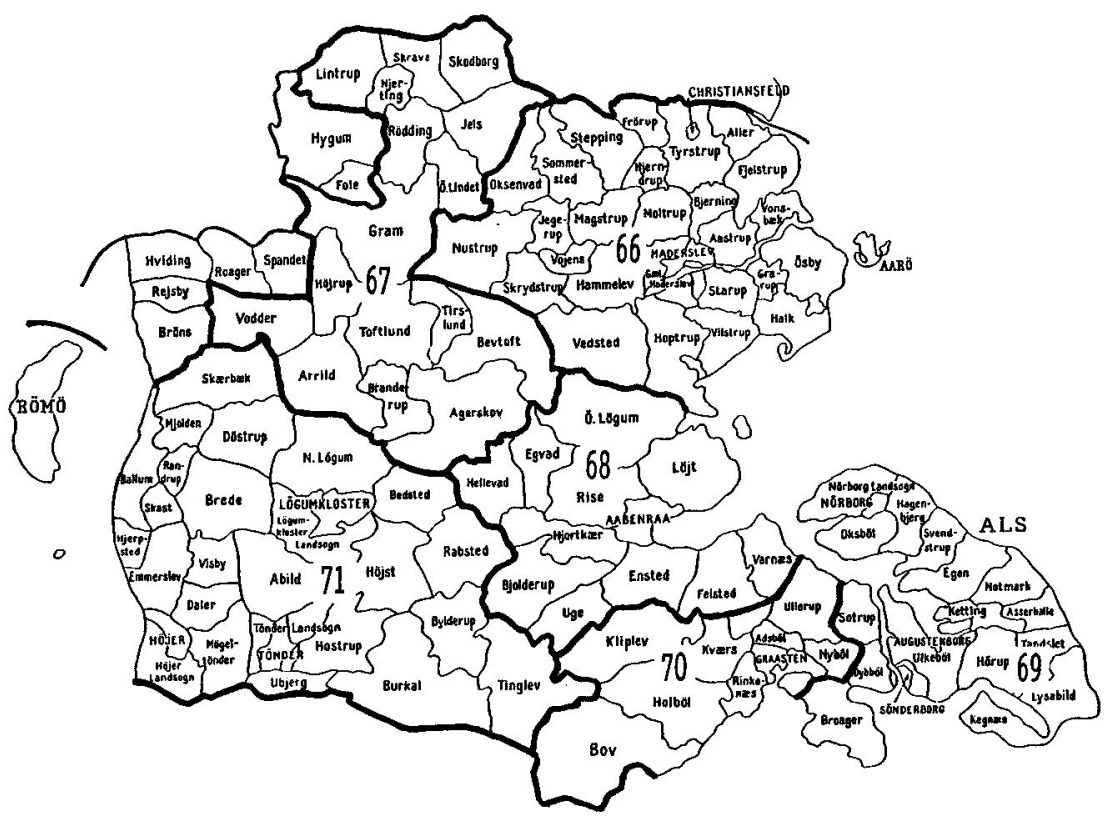

Inddelingen af de sønderjyske politikredse fra 1923 holdt i nøjagtig 50 år til en storre omlagning fandt sted $i 1973$. 
tyske retsgrundlag. De fleste bortfaldt dog i løbet af 1920 'erne. ${ }^{44}$ Af de mere betydende og længerevarende undtagelser, som havde direkte betydning for underretternes virksomhed, var det preussiske grundbogsvæsen, som justitsministeren fandt anledning til at bevare. Nok var det indviklet, men samtidig praktisk, og i ministeriet gik man endog med tanker om at indføre et tilsvarende system i hele Danmark. ${ }^{45}$ Det skete imidlertid ikke, og dansk tinglysningsret indførtes i Nordslesvig den 1. april 1927, samtidig med at tinglysningsbestemmelserne i Danske Lov fra 1683 endelig veg for en moderne dansk tinglysningslov. ${ }^{46}$ Grundbogsbladene videreførtes dog som tingbøger helt indtil de $\mathrm{i}$ midten af 1950'erne blev omskrevet til moderne tingbøger. ${ }^{47}$

Den gradvise indførelse af dansk ret krævede et betydeligt arbejde med at formidle de nye regler til administration og befolkning. Derfor udgav Statsministeriet ved højesteretssagfører N.Cohn og overretssagfører O. P. Schlichtkrull i årene 1920 og 1921 en særlig »Retstidende for de sønderjydske Landsdele«. Heri optryktes de mange nye love, bekendtgørelser og cirkulærer, og der bragtes en række administrative afgørelser, hvoraf mange skulle tjene som mønster for administrationen. Endelig indeholdt retstidenden adskillige vejledninger og bemærkninger til lovene f.eks. vedr. told og skat, privatret, forsikring, forsørgelsesret etc. Mens retstidendens form og sprog gjorde, at den næppe nåede ud til brede kredse $\mathrm{i}$ befolkningen, var den et nyttigt redskab for administrationen - og er i dag en fortræffelig kilde til overgangstidens mange bestemmelser. ${ }^{48}$

\section{Matrikelvæsen, domæner, televæsen}

Med etableringen af amtsadministrationen, politiet og domstolene var de embeder, som var de vigtigste for hævdelsen af dansk suverænitet og retshåndhævelse over de sønderjyske landsdele, på plads. Af de øvrige forvaltninger kunne de fleste indføres i den genforenede landsdel uden større vanskeligheder. Inden for finansforvaltningen etableredes der amtstuer i Haderslev, Aabenraa, Sønderborg og Tønder og toldkamre i Haderslev, Aabenraa, Padborg (med Kollund-Kruså), Egernsund (med Graasten), Sønderborg og Tønder (med Højer). Hertil knyttede sig grænsegendarmeriet, der flyttede ned til den nye grænse. Finansforvaltningens rammer opretholdtes stort set uændrede til 1969/70.49

I hvert af de sønderjyske amter udpegedes en embedslæge. De fire købstæder fik statsskoler, Haderslev og Tønder statsseminarier. En række væsner og etater udstrakte deres virksomhed til den genvundne landsdel gennem oprettelse af nye distrikter og kredse: 7.udskrivningskreds fik hjemsted i Sønderborg, 19. fabriksinspektørkreds i Aabenraa, 5. overpostinspektorat i Haderslev, 
4. teleingeniørdistrikt i Aabenraa. DSB etablerede 10. og 11.trafiksektion i Aabenraa og Tønder, 15. og 16. banesektion i de samme byer samt 6 . maskinsektion i Tønder. Statsskovvæsnet inddeltes i Haderslev, Aabenraa, Sønderborg og Nørre Flensborg statsskovdistrikter, men sidstnævnte faldt allerede i 1921 bort til fordel for Lindet. ${ }^{50}$

På tre områder måtte den nye administration imidlertid bygge direkte på de preussiske traditioner: matrikelvæsnet, domæneforvaltningen og telefonvæsnet.

Ligesom grundbogsvæsnet længe blev bevaret i sin preussiske form, videreførtes også det preussiske matrikelvasen i sine hovedtræk. Det danske matrikelvæsen var centralistisk opbygget med Matrikeldirektoratet i København, der gav de nødvendige tilladelser og dispensationer, og med privatpraktiserende landinspektører, der mod betaling fra rekvirenterne udførte de praktiske opgaver i marken. Det preussiske var i forhold hertil mere decentralt og kendte ikke til private landinspektører. De statslige »Katasterämter« tog sig såvel af det praktiske arbejde med at vedligeholde matriklen som udstedelse af tilladelser. I Nordslesvig fandtes sådanne katasterkontorer i Haderslev, Toftlund, Aabenraa, Sønderborg og Tønder.

Landbrugsministeren foreslog, at det preussiske system i det store hele opretholdtes med de nævnte kontorer, og at staten til at lede kontorerne ansatte fem amtslandinspektører, hvoraf den ene med titel som stiftslandinspektør skulle varetage koordinationen mellem de sønderjyske kontorer og sørge for ensartethed. Derudover skulle der ansættes amtslandmålere. Venstre og konservative var skeptiske overfor tanken om statsansatte landinspektører. Klaus Berntsen (V) mente: »Det er for meget overladt til embedsmændene« og foretrak de private landinspektører. Alexander Foss (C) og Niels Neergaard (V) mente, at amtslandinspektørerne i det mindste delvis skulle være provisionslønnede.

En betænkning fra kontorcheferne for 1. og 3. kontor i Matrikelstyrelsen anførte imidlertid så mange argumenter for den foreslåede ordning, at modstanden blev opgivet og loven udformet som foreslået. Kontorcheferne mente således, at den danske ordning med landinspektører, der konkurrerede om arbejdet, ikke var god for kvalitetsniveauet. Indførte man den generelle danske ordning, skulle der ansættes adskillige i direktoratet, og så ville der ikke være sparet så meget. En opretholdelse af den preussiske model ville endvidere sikre forbindelsen mellem matrikel og grundbøger, som var bedre end sammenhængen mellem matrikel og tingbøger i kongeriget. Man troede desuden, at det ville være vanskeligt at skaffe kvalificerede landinspektører til Sønderjylland, da de bedste havde gode forretninger nord for Kongeåen. Når dertil lagdes, at sønderjyderne var vante til det preussiske system og ønskede det 
opretholdt, og at arkiverne mestendels forblev i landsdelen, og endelig at det preussiske system efter en objektiv faglig vurdering var det bedste, var der meget der talte for at beholde det. Imod talte kun, at man ville få et system forskelligt fra det øvrige land og at befolkningen ikke frit ville kunne vælge blandt landinspektørerne, et valg, som kontorcheferne dog fandt temmelig illusorisk.

Kontorcheferne mente endda, at en sønderjysk særordning kunne tjene som forsøgsordning for hele landet. ${ }^{51}$ Det forholdt sig altså efter den daværende tankegang med matrikelvæsnet på samme måde som med personregistreringen: det preussiske system var simpelthen bedre, og man burde derfor indføre noget tilsvarende i Danmark. ${ }^{52}$ Situationen er også parallel ved, at det endnu i 1995 ikke er sket. Det særlige sønderjyske matrikelvæsen består i vid udstrækning fortsat, fra 1983/84 som et afdelingskontor af Matrikelstyrelsen (fra 1989 Kort- og Matrikelstyrelsen) med en chef $i$ landsdelen. Samtidig blev kontoret i Toftlund nedlagt, og amtslandinspektørerne skiftede navn til statslandinspektører. $^{53}$

Som et led i bestræbelserne for at sikre mest muligt af den sønderjyske landbrugsjord på tyske hænder havde den preussiske stat fra 1896 og helt frem til krigstiden opkøbt 36 store gårde og omdannet dem til domænegårde, som staten forpagtede ud. Ved Genforeningen overgik disse gårde til dansk statsejendom. Det var tanken at lade dem udstykke til husmandsbrug og sælge de tiloversblivende stamparceller, men de gældende forpagtningsaftalers perioder skulle overholdes, og udstykningen kunne ikke sættes i værk på én gang. Til at administrere forpagtningsaftalerne, herunder at føre tilsyn med forpagterne, oprettedes ved lov af 1.april 1921 med øjeblikkelig virkning et embede som statslig domaneforvalter. Domæneforvalteren blev endvidere formand for det tremandsudvalg, landbrugsministeren nedsatte med henblik på at behandle generelle sager vedr. domænerne såsom udstykning og salg. ${ }^{54}$

Til domæneforvalter udpegedes gårdejer P.J.Refshauge fra Oksbøl ved Haderslev. Refshauge var mangeårig formand for Fælleslandboforeningen for Nordslesvig og havde i afstemningstiden været landråd for den internationale kommission i Haderslev kreds. Han havde derfor en omfattende landbrugsfaglig og administrativ viden. Refshauge administrerede også Strågård ved Aabenraa, Krusågård, Grøngård og Trøjborg, Gråsten ladegård og Fiskbæk, som den danske stat købte. Efterhånden som kontrakterne udløb, blev der mindre og mindre at administrere, og pr. 1.april 1935 blev domæneforvalterembedet nedlagt. ${ }^{55}$

Post-, telegraf- og telefonvesen var i Preussen samlet i et fælles statsligt væsen. I Danmark var telefonvæsnet derimod overladt til koncessionerede selskaber som Jydsk Telefon Aktie-Selskab, mens post- og telegrafvæsnet også her 


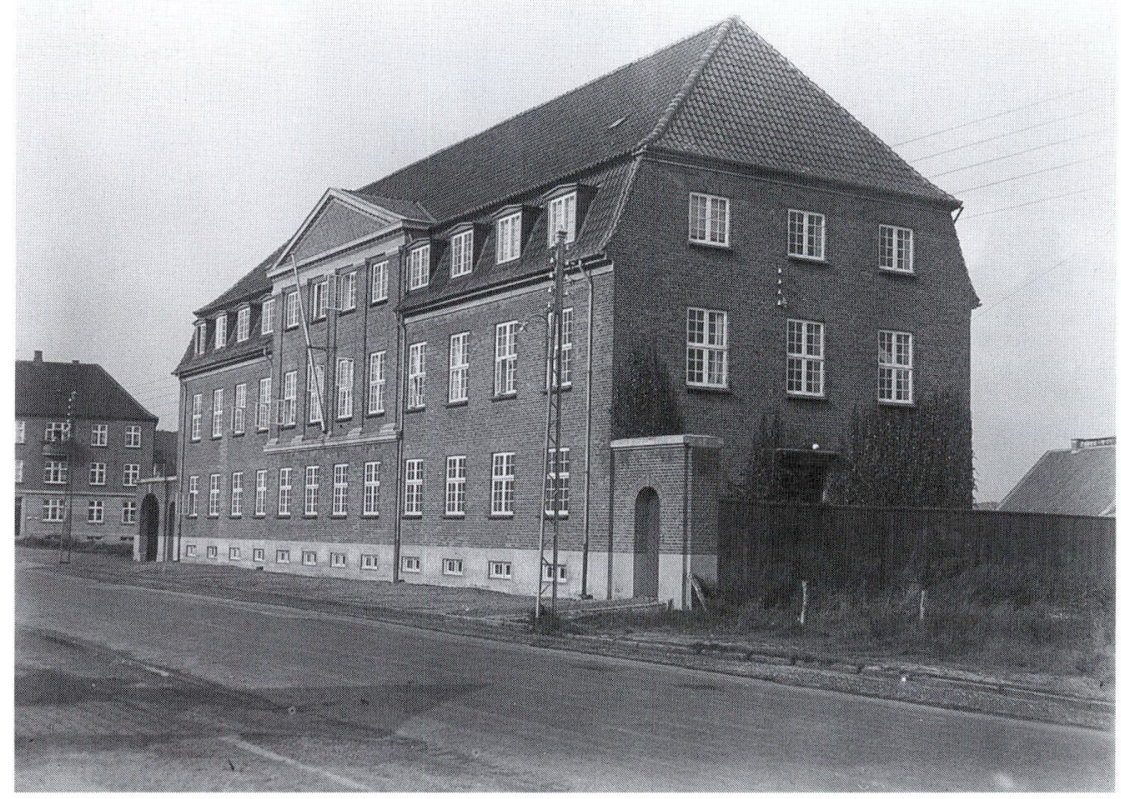

De fleste af de nye danske embeder kunne $i 1920$ fytte ind $i$ de tyske forgangerembeders bygninger. Den rivende udvikling $i$ telefonvasnet nødvendiggjorde imidlertid snart en storre nybygning til Post-og Telegrafvasnets 2. ingeniordistrikt. I 1920 var der således knap 2800 telefonabonnenter $i$ Sonderjylland, i 1926 var der ca. 10.000. Den nye bygning på H. P. Hanssensgade i Aabenraa blev opfort $i 1925$ af arkitekt Jep Fink $i$ en palalignende stil, som var typisk for tidens offentlige bygninger. Rud. Olsen fot. i Institut for sonderjysk Lokalhistorie.

var statsligt. Der var imidlertid enighed om, at telefonvæsnet i Sønderjylland skulle forblive statsligt og om, at nettet skulle udbygges med forbindelser mellem de sønderjyske og nørrejyske byer samt flere centraler og ledninger i selve landsdelen. Anlæg og drift heraf blev varetaget af telegrafvæsnets 4. ingeniørdistrikt i Aabenraa (fra 1927: 2.ingeniørdistrikt, fra 1980: teleregion 2, Sydog Sønderjylland, fra 1986: Tele Sønderjylland). ${ }^{56}$ Med omdannelsen af Tele Sønderjylland til aktieselskab i 1990 og samlingen af de danske teleselskaber i Tele Danmark A/S er den sønderjyske særstilling inden for telesektoren under afvikling.

\section{Afslutning}

Den fælles målsætning, den fuldstændige indlemmelse af den genforenede del af Sønderjylland i kongeriget Danmark, blev i det væsentligste fuldført på 
statsforvaltningens område. På de vigtigste områder, amtsadministrationen, politiet og domstolene, der særlig repræsenterede statsmagtens suverænitetsog retsudøvelse, var der efter det første årti kun ubetydelige rester af preussisk forvaltningstradition tilbage. På de mere teknisk betonede områder som personregistrering, tinglysning og matrikelvæsen blev flere af de preussiske systemer derimod opretholdt, fordi de var bedre end samtidens danske. Domænegårdene var også et levn fra den preussiske tid, som det tog tid at få afviklet. I det sønderjyske telefonvæsen var statsligheden også i pagt med preussisk tradition, mens der på det tekniske område blev foretaget gennemgribende forbedringer.

Kun i få og begrænsede tilfælde blev der tale om en organisering af forvaltningen på tværs af Kongeågrænsen. Overgangstidens mange praktiske problemer tilsagde generelt, at de tilgrænsende kongerigske statslokalforvaltninger ikke fik underlagt sønderjyske områder. I virkeligheden kom kun den gejstlige stiftsinddeling for alvor til at bryde dette mønster.

Til en vis grad blev de sønderjyske landsdele brugt som en administrativ forsøgsmark. Der ansattes tildels ikke-jurister som amtmænd med amtsassessorer som medhjælpere, ordenspolitiet blev statsligt, amtslandinspektørerne ligeså, og der var tanker fremme om senere at indføre principper fra den preussiske personregistrering, grundbogsføring og matrikel i dansk administration. Disse forsøg bragte dog ikke de store moderniseringer i dansk statsadministration, der først for alvor blev forandret fra 1960'erne.

I 1923 blev der nedsat en administrationskommission, der skulle kulegrave hele den offentlige forvaltning. Kommissionen viede den sønderjyske administration et særligt kapitel i sin betænkning, hvor den dels kom med nogle anbefalinger, dels gav en generel karakteristik af indsatsen i de første år efter 1920. Kommissionen foreslog således antallet af amter reduceret til to, en henstilling, der som nævnt kun tildels blev fulgt. Derimod afskaffede staten amtsassessorerne, som kommissionen allerede i 1924 fandt overflødige.

For så vidt angår resultaterne af den sønderjyske administrations virke udtalte kommissionen sig om »den fra forskellig side fremkomne kritik « på grundlag af oplysninger indhentet fra særlige sagkyndige, de sønderjyske rigsdagsmænd, sognerådsforeningerne og cheferne i forvaltningen. Kritikken gik navnlig på langsommelighed i sagsbehandlingen, manglende svar på forespørgsler, manglende angivelse af begrundelse ved afgørelser samt for stærk centralisme med for mange afgørelser samlet $i$ København.

I det store hele frikendte kommissionen imidlertid den sønderjyske administration: »Den forvaltningsmæssige omvæltning, som tilbageførelsen af de sønderjydske landsdele bevirkede, er blevet gennemført $\mathrm{i}$ et langt hurtigere tempo end almindeligt ved tilsvarende forandringer. I Elsass Lothringen og de til 
Polen henførte tidligere tyske landsdele er således ophævelsen af tysk ret og administration endnu ikke fuldstændig gennemført. Mange af de fremkomne klager har netop relation til de vanskelige spørgsmål, som overgangen fra tysk til dansk ret fremkaldte, men under hensyn til disse spørgsmåls vanskelighed kan kommissionen ikke anse denne kritik for beføjet, ligesom der her er tale om overgangsforhold, der allerede i det store og hele er afviklet. I det hele er det kommissionens opfattelse, at de anker, der er fremført overfor den danske administration, i virkeligheden ikke er af meget vægtig eller indgribende art «. ${ }^{57}$

Selv om denne dom blev afsagt af embedsværkets egne repræsentanter, vil den nok også kunne stå for en historisk vurdering i 1995.

\section{NOTER OG HENVISNINGER}

1. Tillæg til kongelig dansk Hof- og Statskalender 1920 indeholdende Oplysninger vedrørende de sønderjydske Landsdele, Kjøbenhavn 1920, sp. 13-14.

2. Cit. efter: Steen Bo Frandsen: Men gives der da Provindser i Danmark? Historie ny række 19:1, 1991, s. 129 f.

3. Svend Thorsen: De danske ministerier 1901-1929, Kbh. 1972, s. 304-309, 323f, 383f. Wilhelm von Rosen (red.): Rigsarkivet og hjælpemidlerne til dets benyttelse, II:1, Kbh. 1991, s. 479-482.

4. Forhandlinger i Rigsdagspartiernes sønderjydske Udvalg 1919-20. Kbh. u. år (herefter: Forhandlinger).

5. Fr. von Jessen: Haandbog i det slesvigske Spørgsmaals Historie, II, Kbh. 1938, s. 241f, 544 (herefter: Fr. von Jessen).

6. Statstidende 5.5.1920. Jfr. Von Jessen Il, 428, 430 og Bekendtgørelser fra Den internationale Kommission for Slesvig, 1920, nr. 98, 101.

7. Sønderjydske Kundgørelser udgivet af Administrator for de sønderjydske Landsdele. Aabenraa, Nr. 1-4, 1920.

8. Retstidende for de sønderjydske Landsdele udgivet af Statsministeriet, 1920, s. 801 (herefter: Retstidende).

9. Forhandlinger, s. 86f.

10. Karl Peder Pedersen: Kan kun jurister være gode amtmænd? Historien om Ove Rodes forgæves forsøg på at bryde juristernes amtmandsmonopol. Arkiv 14:2, 1992, s. 113-118.

11. Forhandlinger, s. $126 \mathrm{f}$.

12. Forhandlinger, s. 127-30.

13. Forhandlinger s. 165.

14. Forhandlinger s. 335-336, 378-382, 594-602, 608-611, 686.

15. Retstidende 1920, s. 295 f (lovens paragraf 8).

16. Fr.von Jessen III, s. 507.

17. Lovtidende 1931, s. 2029.

18. Lovtidende 1927 , s. 55.

19. Kilden til de følgende personalhistoriske oplysninger er Kraks Blaa Bog 1929.

20. Otto Didrik Schack: Grænsesind. Optegnelser fra årene 1913-49, Kbh. 1970, indeholder desvarre intet om amtmandsvirksombeden.

21. Se om arkivdelingen Hans H. Worsøe: Den arkivalske grænse. I: Grænsen i 75 år. Aabenraa 1995, s. 268-296.

22. Peter Chr. v. Stemann: En dansk Embedsmands Odyssé, I, Kbh. 1961, s. 37-78, citat fra s. 69.

23. Om amtsforstanderne: G. Japsen: Amtsforstanderinstitutionen i Nordslesvig. Festskrift til Johan Hvidtfeldt. Aabenraa 1978, s. 189-207. 
24. Gerd Stolz: Geschichte der Polizei in Schleswig-Holstein. Heide 1978, s. 21-44.

25. Politikundskab. Rigspolitichefen. Politiskolen u. år, 1, s. I:4-6.

26. Forhandlinger s. 194.

27. Forhandlinger s. 104-108, 130-131, 137, 161-163, 194, 688, 722.

28. Retstidende 1921, s. 255.

29. Fritz Jacobsen blev i 1934 politimester i Aabenraa. Efter det tyske mindretals nazificering og under den generelle uro i $1930^{\circ}$ erne udnævntes han påny til politiadjudant for de sønderjyske landsdele med henblik på at koordinere de sønderjyske politikredses indsats, se herom J. Hvidtfeldt: Det sønderjyske politiadjudantembedes arbejde. Sønderjyske Årbøger 1957, s. 1-15 samt Henning Koch: Demokrati slå til! København 1994, s. 114-120.

30. Tillæg til Hof- og Statskalender 1920, sp. 20.

31. A. N. Jensen: Minder fra min gerning som politimand omkring genforeningen i 1920 . Sønderjysk Månedsskrift 1956, s. 161-173, citater s. 170, 173.

32. Fr. von Jessen III, s. 32f.

33. Forhandlinger s. 205f.

34. Forhandlinger s. 165.

35. Forhandlinger s. 164-65, 278, 335-36, 379-82, 608-11, 685f, 736-38, 1322f, 1483ff.

36. Forhandlinger s. 1498.

37. Retstidende 1920 s. $220-222$.

38. Lovtidende 1920, s. 1236-39 og 1922, s. 2432f, $2498 \mathrm{f}$.

39. Retstidende 1920, s. 222.

40. Tillæg til Hof- og Statskalender 1920, sp. 19.

41. Retstidende 1920 , s. 221.

42. Forhandlinger s. 164-165, 205. Retstidende 1920, s. 132, 220 f.

43. Lov om ændringer $\mathrm{i}$ og tilføjelser til lov om rettens pleje, der ophævede den midlertidige lov om rets- og politivæsnet i Sønderjylland fra 1920 (Lovtidende 1927, s. 1186-1189). I 1982 kom Landsrettens store bibliotek med tysk og dansk juridisk litteratur til Landsarkivet i Aabenraa.

44. En status giver O. A. Borum: Oversigt over den i de sønderjydske Landsdele endnu gældende Særlovgivning. Kobenhavn 1931.

45. Forhandlinger s. 1331. En dansk vejledning herom blev udgivet af N. Cohn: Grundbogslovgivningen i de sønderjydske Landsdele, København 1920.

46. Lovtidende 1926, s. 594-609, 1306, 1317-1333.

47. Lars N. Henningsen: Ejendomshistorie i Nordslesvig. Aabenraa 1983, s. 18.

48. Retstidende 1920 og 1921. John Skonberg: Retstidende for de sønderjyske landsdele 1920-1922. Sønderjyske Årbøger 1980, s. 73-92.

49. Retstidende 1920 , s. 307,398 og 452-468. Om toldvæsnet endvidere: Toldvæsen og Grænsegendarmeri. En registratur udgivet af Landsarkivet for de sønderjyske Landsdele. Aabenraa 1987 og Anders Monrad Moller: Toldkontrol og grænsebevogtning. Grænsen i 75 år. Aabenraa og København 1995, s. 44-64. Om grænsegendarmeriet: Jens Jensen: Det danske Grænsegendarmerikorps grænsens gendarmer og smuglere. Med en efterskrift af Lars Bjørneboe. Toldhistorisk Selskab, København 1981, s. 161-213.

50. Retstidende 1920, s. 275, 305f, 316f, 343f, 389f, 391, $426 \mathrm{f}$.

51. Forhandlinger s. 344-347, 353-357, 505-512, 535-538, 1519-1522. Retstidende 1920, s. 357f.

52. Se herom Hans H. Worsøes artikel: »Den borgerlige personregistrering i Sønderjylland i denne årbog s. 293-312.

53. Landinspektøren nr. 1-95 er et jubilæumsnr. for det sønderjyske matrikelvæsen.

54. Retstidende 1921, s. 255.

55. Lov om ophævelse af lov nr. 169 af 1 . april 1921 om domæneforvaltningen $\mathrm{i}$ de sønderjydske landsdele. Lovtidende 1934, s. 1237. P. J. Refshauge: Bonden der blev landråd. Aabenraa 1940, s. 155-166.

56. Forhandlinger s. 110, 141-142. Retstidende 1920, s. 343f. Telegrafvæsenet i Sønderjylland. Landsarkivet for de sønderjyske Landsdele. Aabenraa 1992, s. $3 f$.

57. 2den Betænkning afgivet af Administrationskommissionen af 30. Juni 1923. København 1924, s. 113-121, citat fra s. 119 . 
